v. 8, n. 4

Vitória-ES, Oct. - Dec. 2011.

p. 44-66 ISSN 1808-2386 DOI: http://dx.doi.org/10.15728/bbr.2011.8.4.3

\title{
Reasons for outsourcing services in medium and large companies
}

\author{
Marcos Antonio Ferruzzi ${ }^{\dagger}$ \\ Universidade Metodista de Piracicaba (UNIMEP) \\ Mário Sacomano Neto $\Omega$ \\ Universidade Metodista de Piracicaba (UNIMEP) \\ Eduardo Eugênio Spers ${ }^{*}$ \\ Escola Superior de Propaganda e Marketing (ESPM) \\ Mateus Canniatti Ponchio ${ }^{\mathfrak{E}}$ \\ Escola Superior de Propaganda e Marketing (ESPM)
}

\begin{abstract}
This study identifies the reasons firms decide to outsource activities instead of performing them internally. The study is restricted to the logistics, information technology, gate-keeping and/or reception and cleaning services as well as part of the production activities. The research was carried out in two steps. The first one consisted of interviews with four executives of large companies and the second one consisted of a survey of executives of 80 industrial companies and more than 100 direct employees. From the quantitative date we prepared contingency tables, cross-referencing the frequencies of the main factors given as leading the firms to outsource services with the corresponding activities, using Pearson's Chisquare test. The results show that the option for outsourcing is the result of a combination of factors, mainly involving the service to be contracted out and the firm's economic segment. Specialization of services and reduction and control of operating costs were the reasons given most often for outsourcing. This study contributes to the debate over the reasons companies outsource their activities and can serve as a reference for firms involved in the outsourcing processes.
\end{abstract}

Key words: Outsourcing; services; transaction costs; core competencies.

Received on 06/22/2010; reviewed on 10/22/2010; accepted on 10/22/2010; available in 10/21/2011

Corresponding authors*:

\begin{tabular}{|c|c|}
\hline \multirow{2}{*}{\multicolumn{2}{|c|}{$\begin{array}{l}\text { Masters } \\
\text { administration }\end{array}$}} \\
\hline & \\
\hline $\begin{array}{l}\text { University } \\
\text { (UNIMEP). }\end{array}$ & Piracicaba \\
\hline $\begin{array}{l}\text { Institution: Methodist } \\
\text { of Piracicaba (UNIMEP }\end{array}$ & University \\
\hline Address: Av. Eng. & Euzébio \\
\hline Stevaux, 1000, Apt. & 81 Torre \\
\hline 1, Santo Amaro, São & Paulo - \\
\hline SP - Brazil - CEP 046 & 96- \\
\hline $\begin{array}{l}\text { E-mail:marcos.ferruzzi } \\
\text { Telephone: (11) } 9550-9\end{array}$ & $\begin{array}{l}\text { (a) uol.c } \\
979\end{array}$ \\
\hline
\end{tabular}

\begin{tabular}{|c|c|}
\hline & Doctroate \\
\hline $\begin{array}{l}{ }^{\Omega} \text { Ph.D. in production engineering } \\
\text { from São Carlos Federal }\end{array}$ & administration from University of \\
\hline University (UFSCar). & São Paulo (USP). \\
\hline \multirow{2}{*}{$\begin{array}{l}\text { Institution: Methodist University } \\
\text { of Piracicaba (UNIMEP). }\end{array}$} & Institution: Superior School of \\
\hline & Advertising and Marketing \\
\hline Address: Rua Sete de Setembro, & (ESPM). \\
\hline \multirow{2}{*}{$\begin{array}{l}\text { 3148, Centro, São Carlos - SP - } \\
\text { Brazil - CEP: } 13560 / 181 .\end{array}$} & Address: Rua Dr. Álvaro Alvim, \\
\hline & 123. São Paulo-SP-Brazil \\
\hline E-mail: msacomano@unimep.br & CEP 04018-010. \\
\hline \multirow[t]{2}{*}{ Telephone: (16) 34129434} & E-mail: espers@espm.br \\
\hline & \\
\hline
\end{tabular}

${ }^{£}$ Doutor pela Fundação Getúlio Vargas (FGV-SP) Institution: Superior School of Advertising and Marketing (ESPM).

Address: Rua Gaspar Lourenço, 191, Apt. 111-V, São Paulo - SP - Brazil - CEP: 04.107-001. E-mail:mateus.ponchio@gmail.com Telephone: (11) 7337-5932

Note from the Editor: This article was accepted by Antonio Lopo Martinez.

\section{$(\infty))$ BY-NG-SA}

This work is licensed under a Creative Commons Attribution-Noncommercial-Share Alike 3.0 Unported License 


\section{INTRODUCTION}

Many factors lead companies to choose outsourcing. The factors most often mentioned in the literature are: specialization of the service provider; increased focus on the main activity; increased productivity; acquisition and updating of new technologies; absence of internal resources; improved quality of services; increased management flexibility; reduction and control of operating costs; reduction of the need for fixed assets; and increased competitiveness (Anderson \& Weitz, 1986; Belous, 1989; Greer, Youngblood \& Gray, 1999; Gupta \& Gupta, 1992; Kakabadse \& Kakabadse, 2002; Quinn \& Hilmer, 1994; Pires, 2004; Jiang \& Qureshi, 2006; Moses \& Ahlstrom, 2008; Gonzalez, Gasco \& Llopis, 2010).

Outsourcing has been progressively gaining space in the corporate world. Brazilian and multinational companies have increasingly been contracting out activities that were previously performed in-house. A survey by the Brazilian Institute of Geography and Statistics (IBGE, 2007) showed that in Brazil outsourcing of services represented $48 \%$ of all new job positions in the formal sector. If this trend continues, in a few years the majority of workers will start their careers working for outsourced service providers.

A study carried out by Fernandes \& Carvalho Neto (2005) with 513 executives (CEOs and other senior officers) drawn from 179 of the 500 largest companies in Brazil concluded that the number of outsourced workers in these companies was greater than the number of direct employees. This result is significant because it shows that among the country's largest firms, outsourcing of services is a widespread practice.

There are many theories about the reasons for outsourcing. According to Spiegel (1993), Hamel \& Prahalad (1994), Byrne (1996), Robles (2001), Pires (2004), Busi \& McIvor (2008) and Gonzalez, Gasco \& Llopis (2010), among others, outsourcing of services has become a common practice among firms that operate in highly competitive and internationalized markets. As stressed by Busi \& McIvor (2008), the theme of outsourcing is related to at least ten theoretical perspectives: (1) transaction cost theory; (2) resource-based view; (3) principal-agent theory; (4) vertical integration theory; (5) strategic management; (6) evolutionary economics; (7) market relationship theory; (8) industrial economics; (9) strategic alignment theory; and (10) core competence theory. In this study we considered core competence theory and transaction cost theory in the literature review and the results.

Due to the wide scope of outsourcing of services, there was a need to delineate the activities to be considered in the analysis. Therefore, this study is restricted to the outsourcing of logistics, information technology, gate-keeping and/or reception desk and cleaning 
services, as well as parts of the production process. The choice of these activities was based on the aggregate value these services represent in the national economy and the large number of workers engaged in performing them.

The study seeks to answer two basic questions: What factors prompt companies to outsource their services, and is there a relationship between the type of service and the motivating factors for outsourcing? We also test two hypotheses: $\mathbf{H}_{\mathbf{0}}$ : There is no relation of dependence between the type of service and the factors motivating outsourcing; and $\mathbf{H}_{\mathbf{a}}$ : There is dependence between the type of service and the factors motivating outsourcing. These research questions and hypotheses are analyzed in the study's results.

The study was carried out in two steps. The first, with exploratory character, involved in loco interviews at four large industrial companies (with over 1,000 employees), in the electrical-electronic, pulp and paper, textile and food sectors. The second step consisted of online response by 80 executives and over 100 direct employees of industrial companies to a questionnaire on the reasons for outsourcing services.

\section{THEORETICAL FRAMEWORK FOR STUDYING OUTSOURCING}

In this section we present the central elements of the outsourcing process and some theories related to the theme. For this purpose, we examine outsourcing and its relationship with reduction of costs and enhancement of competitiveness. Then we address two theoretical perspectives for the study of outsourcing: the transaction cost theory of Williamson (1975 and 1985) and the core competence theory, based on Hamel \& Prahalad (1998).

\subsection{OURSOURCING: REDUCTION OF COSTS AND ENHANCEMENT OF COMPETITIVENESS}

In many studies of outsourcing, one of the main arguments presented for subcontracting services as opposed to vertical integration is cost savings (Anderson \& Weitz, 1986; Belous, 1989; Greer, Youngblood \& Gray, 1999; Gupta \& Gupta, 1992; Lever 1997; Kakabadse \& Kakabadse, 2002; Jagersma \& Gorp, 2007).

According to Quinn et al. (1990), all organizations that seek competitiveness by means of high productivity and quality must control their costs. For many companies, the highest expense item is fixed costs, so cutting these should be a priority for all firms.

For Quinn \& Hilmer (1994), there are two strategic approaches that, when properly combined, allow managers to leverage the skills and resources of their organizations beyond 
the levels obtainable through other strategies. These two strategies are to concentrate the organization's resources on its own core competencies and to outsource activities that are not strategic to the organization or for which it does not have a special capacity.

According to Hessel (2003), at the end of 2003 IBM closed a huge deal to assume management of the entire human resources area of Procter \& Gamble (P\&G). The deal was worth US\$ 400 million, covered a period of 10 years and could be renewed. According to the contract, IBM assumed responsibility for managing the payroll, compensation planning, expatriate and relocation services, business travel and human resources records of all the companies of the P\&G Group.

As reported by Polônio (2000, p. 37), “[...] the savings on labor and social security charges by service takers is often put in first place, in detriment to the greater objective of the process." In this respect, the search for immediate cost reductions, without concern for how this is done and the potential advantages over the medium term, often leads to an undesired labor liability. ${ }^{\mathrm{i}}$

Outsourcing is also directly related to the search for competitiveness. Porter (1999, p. 49) sees outsourcing of services as a strategy seeking the best results and highest competitiveness, and states that "[...] it is difficult to perform all activities as productively as specialists." Therefore, it is preferable to outsource some activities and concentrate on that which the company can do with greater quality and productivity at a lower cost.

India is an emerging country that has invested heavily in technology and the provision of services, and "[...] with $20 \%$ of global exports, has become a world leader in the exportation of information technology services, ahead of Ireland and the United States" (Jornal Folha de S. Paulo, 2006).

In 2004 , over $67 \%$ of the human resources departments in the United States outsourced their services (Bureau of National Affairs, 2004). This fact is relevant because the U.S. has the world's largest market for services, many of which are contracted out.

\subsection{CORE COMPETENCE}

The idea of core competence was utilized by Hamel \& Prahalad (1998, p. 297) to examine the competitive advantage of firms. According to them, in the short run, competitive advantage "derives from the price/performance attributes of the current products", while in the long run it is due to "the ability to build, at lower cost and more speedily than competitors, the core competencies that spawn unanticipated products." 
The best strategy for companies is to concentrate on their core competencies, develop them continuously and increase the edge over the competition. In this way, it is possible to focus on development, production, distribution and marketing of the company's essential products and services. Hamel \& Prahalad (1998, p. 305) call this "physical embodiments of one or more core competencies."

According to Robles (2001, p. 21), the studies of these authors have provided a better understanding of what affects the paths of outsourcing and the reasons managers decide to take this route instead of keeping tasks in-house, explaining there is a "[...] trend to outsource activities not considered essential."

McDermott (2003) performed a study to analyze the relation between core competencies and organizational results and concluded that firms that focus on their core competencies have better skills and are more competitive due to their higher level of performance. Further according to the author, organizational results are directly related to the internal resources and the external setting of the company. However, not all competencies help improve performance. According to McDermott (2003), for a competency to be considered core, it must add value to the customer, make a competitive difference and have a high level of ability.

One of the factors why a firm chooses to outsource services is to transfer activities not related to its core competencies to firms better able to perform them. Since these competencies change, the option for outsourcing can also change over time. If a competency changes, the choice between doing the corresponding activity in-house and farming it out can also change.

Jenster \& Pedersen (2000, p. 150) recognize the difficulty of defining what a core competency is, because the "the concept of core competence has been important for the management strategy of outsourcing" since the 1990s, when the idea gathered strength to focus resources on the firm's main activities and transfer secondary ones to other parties, In their study, Jenster \& Petersen (2000) concluded that the outsourced service provider should not limit itself to developing its own competencies, but also those of its clients. For the authors, competencies can be classified as central, essential, auxiliary and superfluous, and not all are equally important for the company's performance. Faced with a decision on whether to do something in-house or outsource it, firms should focus their efforts on the activities involving their central and essential competencies and contract out the other tasks. 


\subsection{TRANSACTION COST THEORY}

The main proponent of transaction cost theory is Williamson (1975). As discussed in this work it can be used to reach decisions between outsourcing or vertical integration, that is, between internalizing or externalizing activities. The main dimensions by which transactions can be classified are:

1. Specificity: This involves the degree of specialization of a determined transaction. The greater the specialization of the transaction, the more difficult will be the utilization by another organization.

2. Frequency: In this respect, the benefits of a specialized organizational structure are greater for transactions based on specific assets. These structures require greater cost, which will be more easily recouped by recurring transactions. Therefore, frequency is a relevant dimension, and Williamson (1975) classified it as occasional or recurrent.

3. Uncertainty: The more uncertain a transaction is, the greater will be the need for vertical integration.

Based on these dimensions, Williamson (1975) created a reference chart to categorize transactions. Transaction cost theory focuses on economic evaluation, and within this context, works with two behavioral assumptions: the limit of rationality and opportunism.

According to Williamson (1985), rationality implies humans' intentions to act sensibly, according to reason, following the position approved by society. However, in the market, when there is no competition due to monopoly or very few suppliers, economic abuse generally occurs because agents act opportunistically, guided by their own interests, to the extent of becoming predatory and upsetting the market balance. This fact interferes in the decision whether or not to outsource a given activity.

Lilly, Gray \& Virick (2005) mention that when competition is limited, a reduced quantity of goods and services is available, and their prices tend to increase. In this situation, the rationality of the supplier yields to opportunism.

The outsourcing of services makes economic sense. According to Lacity \& Hirschheim (1993), transaction cost theory is most used for analysis of the process of outsourcing services, especially for decisions of an economic order, in which cost versus benefit is considered paramount for choosing the best proposal. 
The model put forward by Williamson (1975) has contributed in the sense of delineating some parameters for the outsourcing process. The greater the specificity of an asset and the uncertainty of a transaction, the more likely the decision will be for verticalization. Otherwise, outsourcing is indicated, but with contracts able to inhibit opportunistic behavior by the parties.

\section{RESEARCH METHODOLOGY}

The study was carried out in two steps. In the first, more exploratory in nature, we interviewed four executives of large companies, using a semi-structured script, according to the denominations of Collins \& Hussey (2005). In the second step we performed a survey of executives of 80 industrial companies and more than 100 direct employees of these firms. All the companies are located in the state of São Paulo, mainly in the region of Campinas, and are engaged in various industrial segments.

The qualitative research was carried out in four companies by means of personal interviews with the executive responsible for outsourcing services, based on the definitions of Collins \& Hussey (2005). The quantitative survey relied on a standard questionnaire with online response by companies contacted in advance by telephone, or by a printed questionnaire, filled in by the manager chosen by the company to participate in the survey. The initial statistical analysis involved tabulating the results and creating graphs of the sample profile and percentage frequency obtained for each question (Pereira, 2001).

Then we formulated contingency tables, according to the method recommended by Pimentel Gomes (2000), to cross-reference the frequencies of the main factors that lead the companies to outsource their services with the sectors that utilize outsourcing principally due to these factors.

For this purpose, we used Pearson's Chi-square test, to evaluate the degree of independence between the type of service and the factor motivating outsourcing.

The qualitative study involved interviews with four executives of large industrial companies (more than 1,000 employees) that outsource services, in the electrical-electronic, pulp and paper, textile and food segments. We purposely chose different segments to better assess the level and perception of managers regarding the outsourcing of services in different industrial areas. 


\section{RESULTS OF THE FIELD STUDY}

The results presented below were compiled from the field study - the first step which was exploratory and qualitative. The second step involved a survey of 80 industrial companies.

\subsection{FIRST STEP OF THE STUDY}

The qualitative research involved interviewing executives of four large industrial companies, as described in Chart 1. According to the four executives consulted, reduction and control of operating costs were the decisive reasons for choosing to outsource services instead of performing them internally.

While three respondents stated that cost reduction is a strict condition for choosing to outsource, that is, if outsourcing implies any cost reduction, it is chosen, one executive categorically stated that his company only outsources when this allows savings of at least $10 \%$.

\begin{tabular}{|l|l|l|l|l|}
\hline & \multicolumn{1}{|c|}{ Company A } & \multicolumn{1}{|c|}{ Company B } & \multicolumn{1}{|c|}{ Company C } & \multicolumn{1}{|c|}{ Company D } \\
\hline Nature & National & National & Multinational & National \\
\hline Organization & Private & Private & Private & Private \\
\hline Turnover & $\mathrm{R} \$ 1$ billion & $\begin{array}{l}\mathrm{R} \$ 500 \text { million to } \\
\mathrm{R} \$ 1 \text { billion }\end{array}$ & $\begin{array}{l}\mathrm{R} \$ 500 \text { million to } \\
\mathrm{R} \$ 1 \text { billion }\end{array}$ & $\begin{array}{l}\mathrm{R} \$ 100 \text { million to } \\
\mathrm{R} \$ 500 \text { million }\end{array}$ \\
\hline $\begin{array}{l}\text { Number of Outsourced } \\
\text { Workers }\end{array}$ & 500 & 200 to 499 & 200 to 499 & 50 to 199 \\
\hline $\begin{array}{l}\text { Number of Service } \\
\text { Providers }\end{array}$ & 1 to 5 & 10 & 6 to 10 & 1 to 5 \\
\hline
\end{tabular}

Chart 1 - Characteristics of the companies involved in the qualitative study

Source: Prepared by the authors.

Even though they were aware of and agreed that there are various advantages of outsourcing, when successful, the respondents focused on cost reduction as the major consideration, in an effort to increase competitiveness.

According to the results of these interviews, while focus on the core activity is an important condition at the time of deciding to outsource services, cost reduction is the crux of the matter, because without it, other reasons are not sufficient.

For the respondents, focus on the main activity is viewed as a competitive advantage at the same level as other factors, such as specialization of the service provider and acquisition and updating of new technologies. 
Regarding the choice of service providers, two of the four companies have used outside consultants to perform a preliminary study of potential candidate firms and to present a shortlist of those considered as best and most prepared. After identification of the leading candidates, the companies and consultants then work together to identify the best choice for the particular activity. The other two companies always have chosen their outsourced service providers internally, without engaging any outside consultants.

\subsection{SECOND STEP OF THE STUDY}

The second step of the study consisted of a survey of 80 large industrial companies. Chart 2 shows the breakdown of the companies according to type of organization and nature of company.

It can be seen that the great majority of companies are privately held $(98 \%)$ and also most are national (61\%).

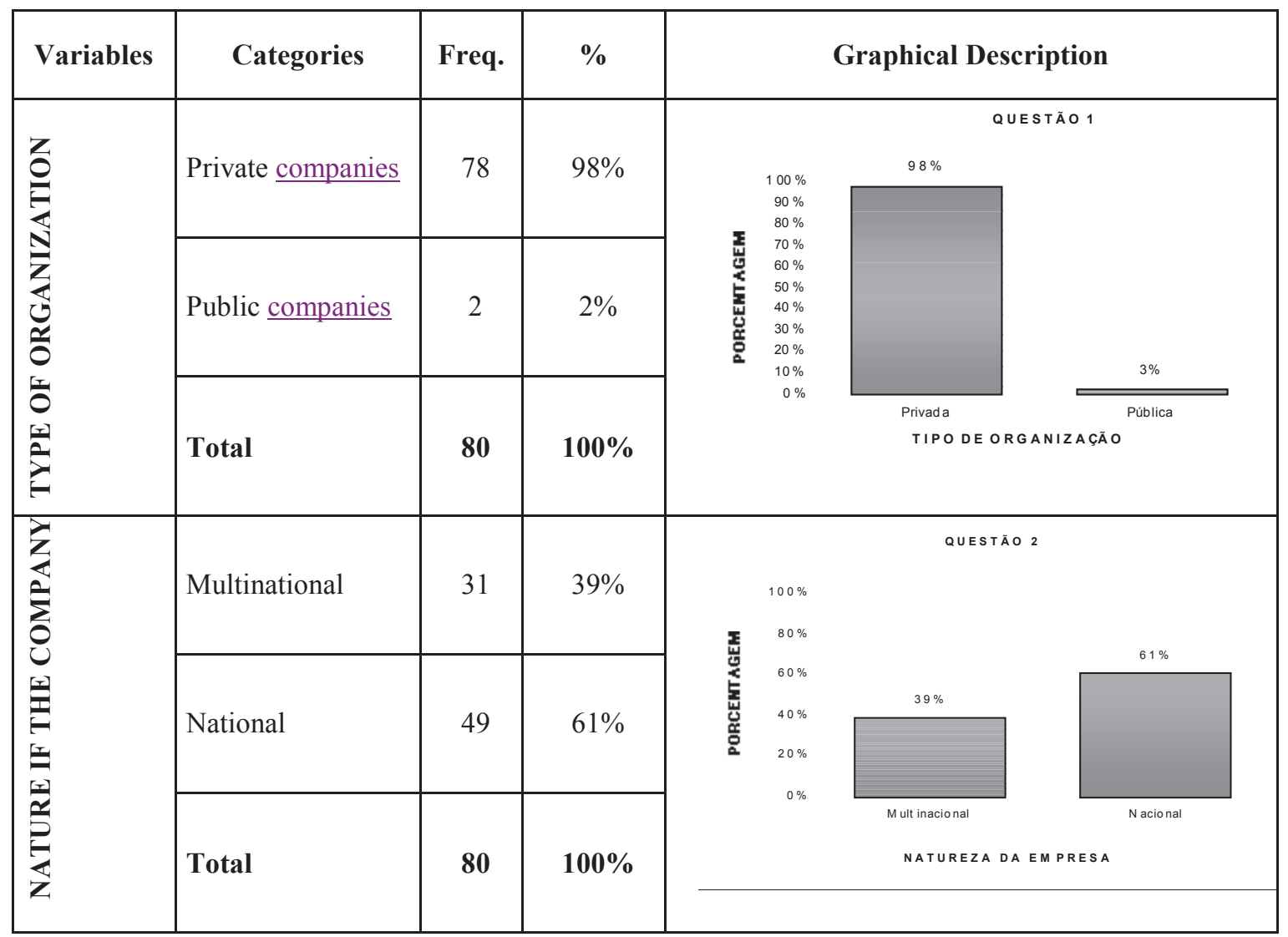

Chart 2 - Tabular and graphical description of the type and nature of the companies

Source: Prepared by the authors.

Chart 3 shows the breakdown of the companies according to segment, while Chart 4 gives more details of those classified as "Other" in Chart 3. 


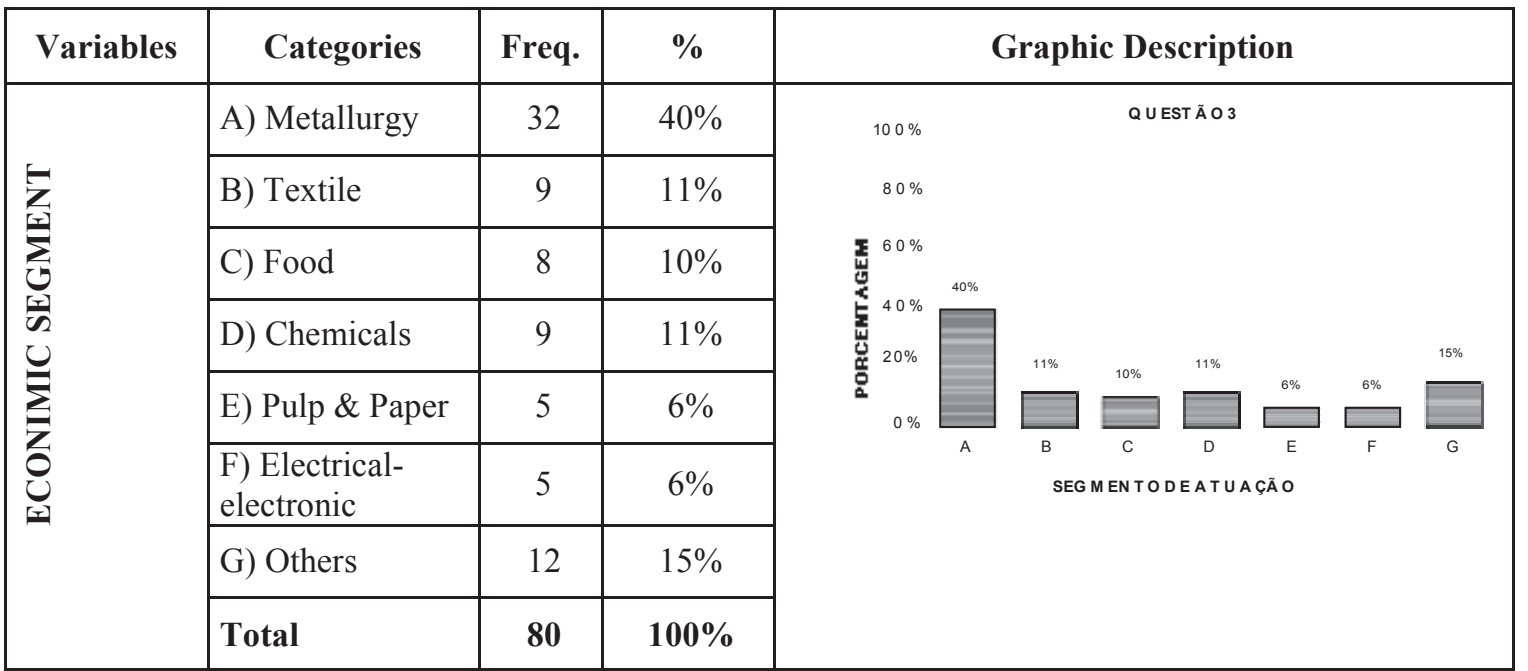

Chart 3 - Tabular and graphical description of the segment of the companies

Source: Prepared by the authors.

As shown in Chart 3, the largest percentage of the companies operate in the metallurgy segment $(40 \%)$, but there are a substantial percentage (15\%) in others, so Chart 4 further describes these companies.

\begin{tabular}{|c|c|c|c|c|}
\hline Variable & Categories & Freq. & $\%$ & Graphical Description \\
\hline \multirow{10}{*}{ 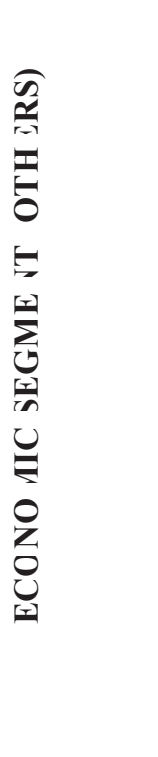 } & A) Agro-industrial & 2 & $17 \%$ & \multirow{10}{*}{$\square \mathrm{A} \square \mathrm{B} \square \mathrm{C} \square \mathrm{D} \square \mathrm{E} \square \mathrm{F} \square^{\mathrm{G}} \square \mathrm{H} \square \mathrm{l}$} \\
\hline & B) Communication & 1 & $8 \%$ & \\
\hline & $\begin{array}{l}\text { C) Petroleum } \\
\text { products } \\
\text { distribution }\end{array}$ & 1 & $8 \%$ & \\
\hline & $\begin{array}{l}\text { D) Glass and glass } \\
\text { fiber }\end{array}$ & 1 & $8 \%$ & \\
\hline & E) Pharmaceutical & 3 & $25 \%$ & \\
\hline & F) Mining & 1 & $8 \%$ & \\
\hline & G) Furniture & 1 & $8 \%$ & \\
\hline & H) Tires & 1 & $8 \%$ & \\
\hline & I) Steel & 1 & $8 \%$ & \\
\hline & Total & 12 & $100 \%$ & \\
\hline
\end{tabular}

Chart 4 - Tabular and graphical description of the segments of the companies

Source: Prepared by the authors.

It can be seen that among these segments, pharmaceuticals obtained the highest percentage $(25 \%)$, followed by agro-industry $(17 \%)$. The others are represented by a single company.

Chart 5 describes the responses regarding the number of employees (not counting outsourced workers). 


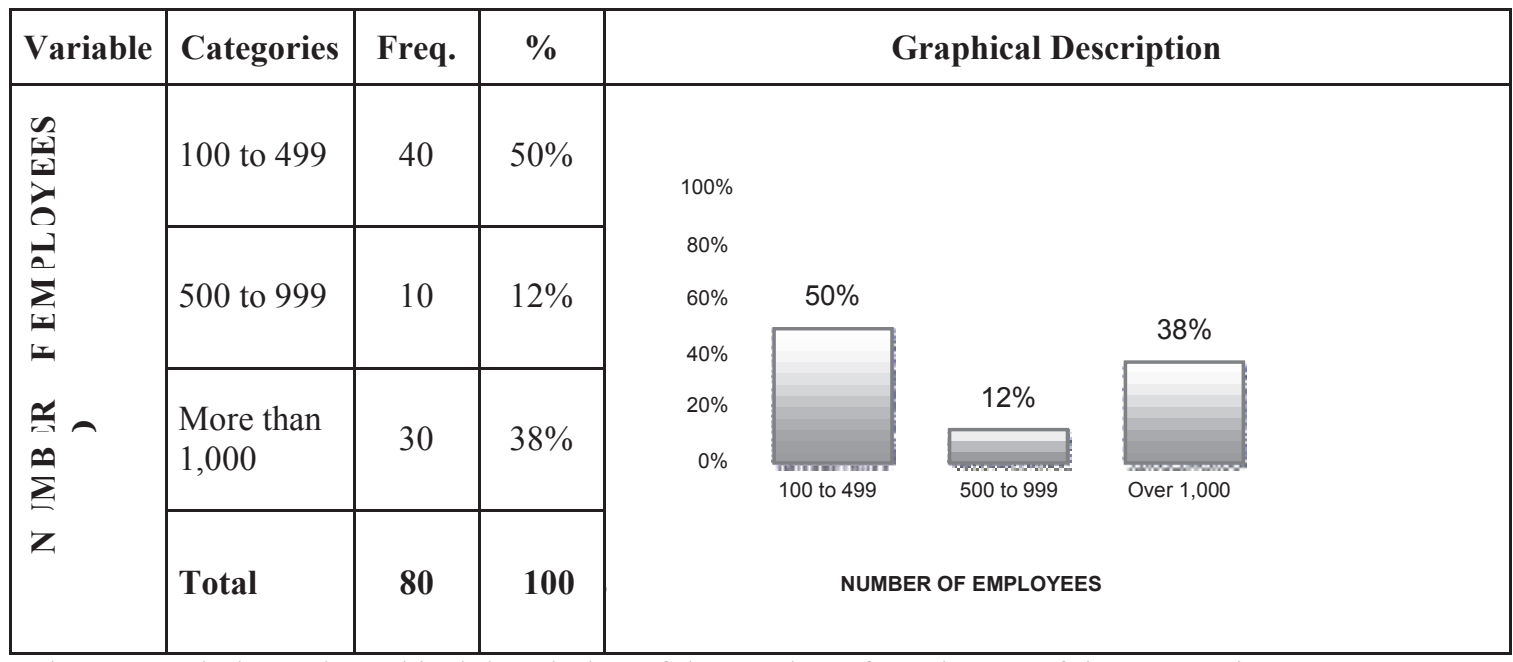

Chart 5 - Tabular and graphical description of the number of employees of the companies Source: Prepared by the authors.

Half of the companies (50\%) that outsource services have between 100 and 499 employees, while $38 \%$ of them have over 1,000 employees and only $12 \%$ have from 500 to 999 employees.

Companies with 100 to 499 employees are considered to be medium-sized while those with headcounts over 500 are classified as large. Therefore, in the sample surveyed 50\% of the companies are large and 50\% are mid-sized.

This even breakdown was obtained by accident, since the only restrictions on participation in the study were being engaged in the industrial segment and having over 100 employees. Although unintentional, this balanced composition of the sample contributed to the evaluation of the factors that prompt both medium-sized and large firms to outsource services.

Chart 6 shows the number of outsourced workers within the companies and the number of service provision firms.

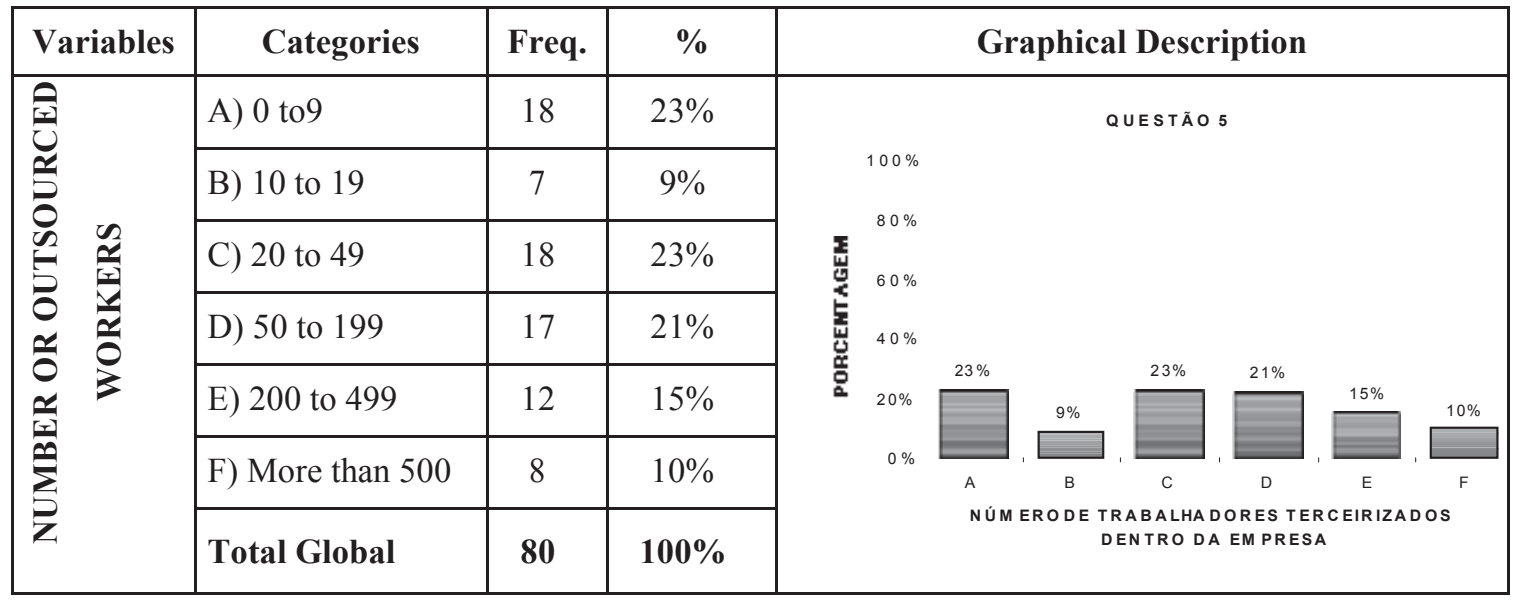




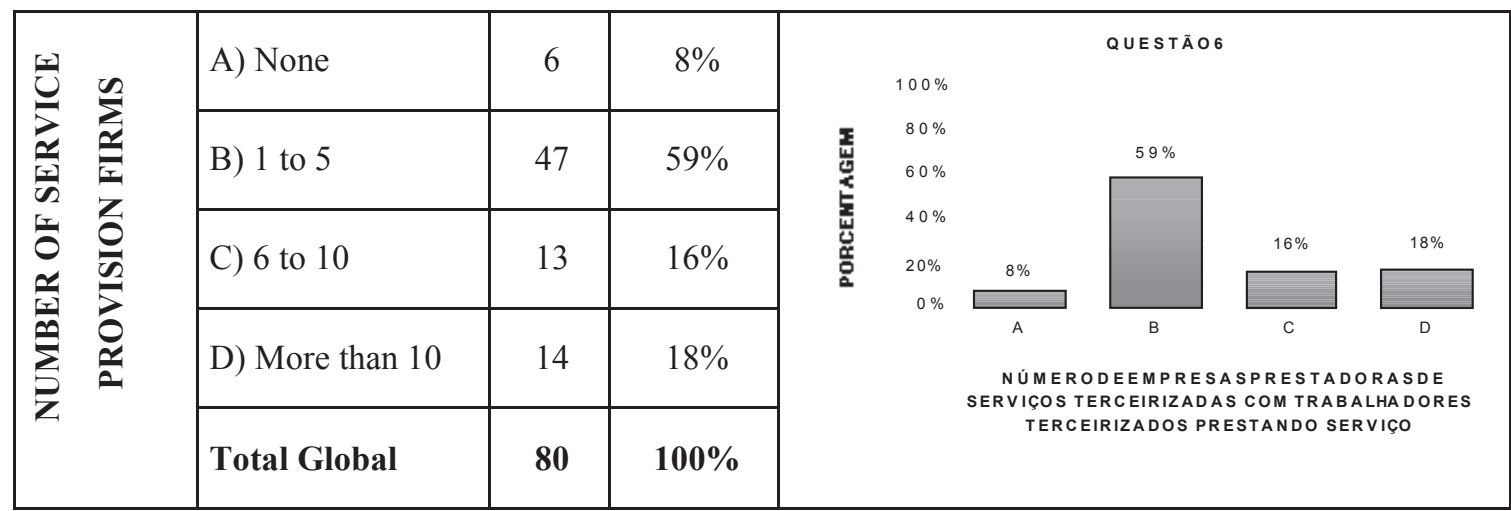

Chart 6 - Tabular and graphical description of the number or outsourced workers and number of service provision firms.

Source: Prepared by the authors.

With respect to the number of service provision firms, the majority (59\%) work with 1 to 5 service providers, while $34 \%$ contract 6 or more firms to provide outsourced workers. Chart 7 shows the description of the gross revenue in 2005 of the companies surveyed.

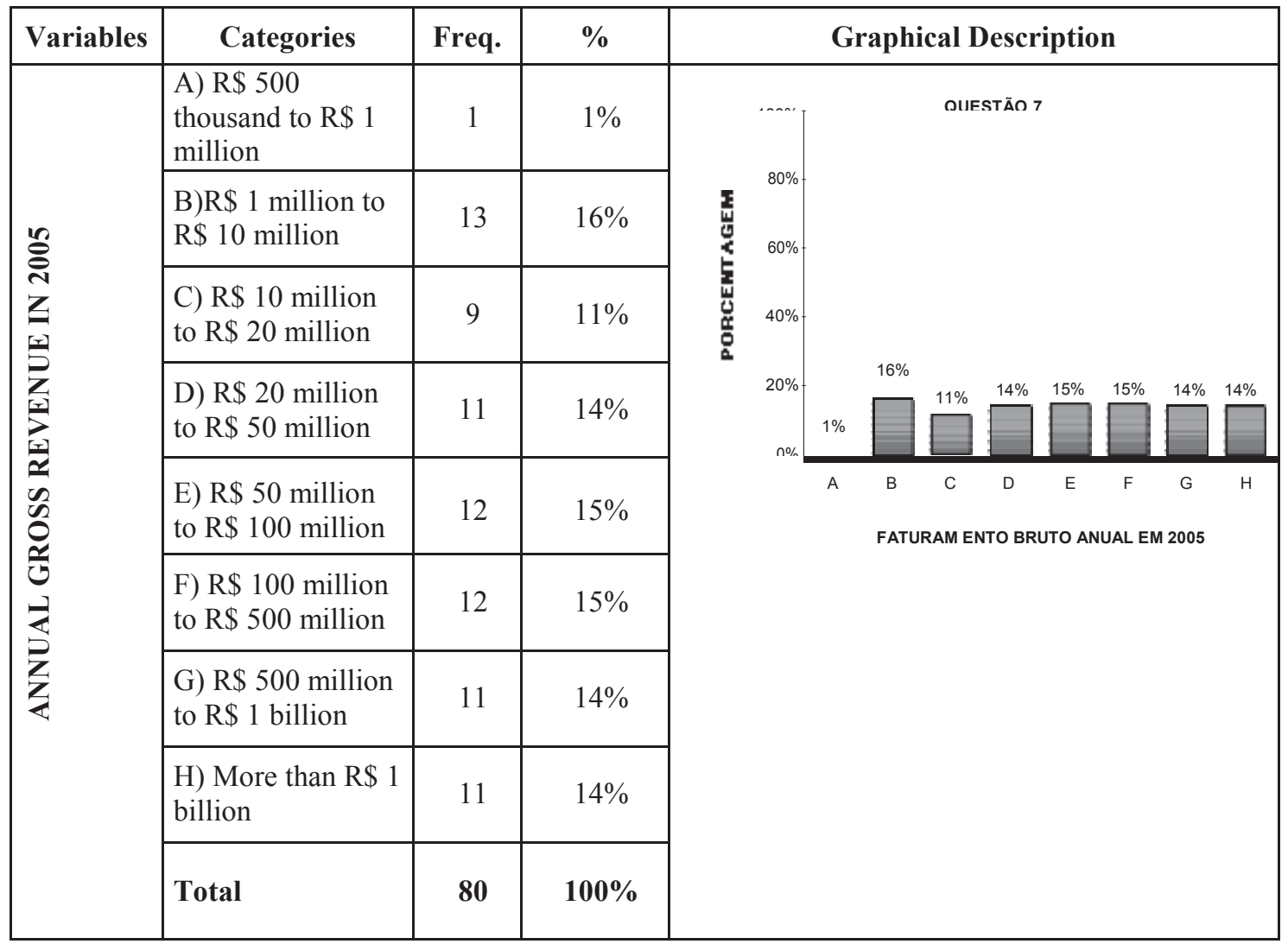

Chart 7 - Tabular and graphical description of the gross revenue of the companies studied.

Source: Prepared by the authors.

It can be seen from Chart 7 that $99 \%$ of the companies had revenue greater than $\mathrm{R} \$$ 1 million in 2005, and that $14 \%$ had revenue that year greater than $\mathrm{R} \$ 1$ billion. Only one company had revenue lower than R\$ 1 million. 
It can also be observed that outsourcing occurs in companies in practically all revenue ranges in nearly the same proportion for those with revenue greater than $R \$ 1$ million, since the percentage in each category is between $11 \%$ and $16 \%$, a difference of only 5 percentage points.

Chart 8 shows the opinion of the managers regarding the main reasons for the success of outsourcing services.

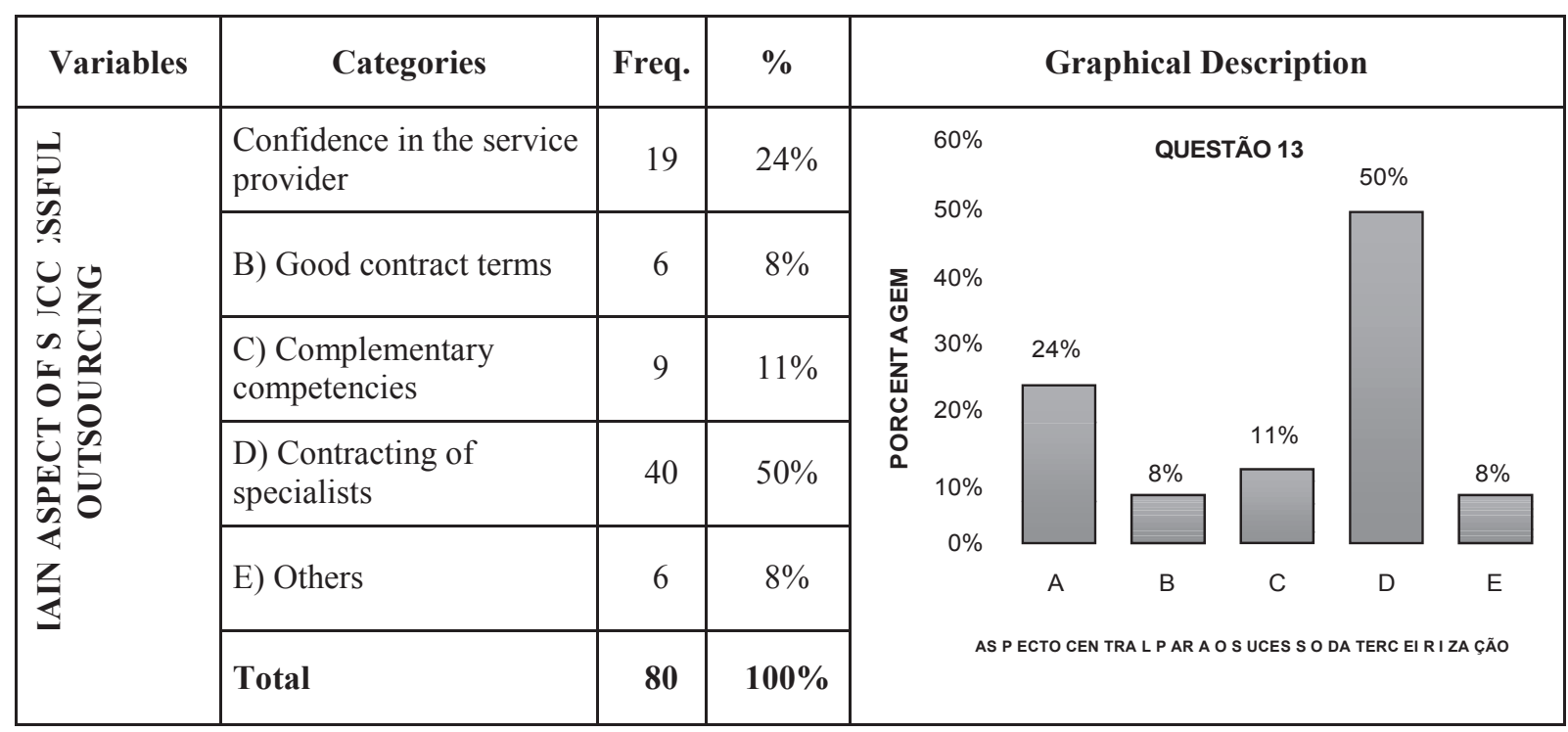

Chart 8 - Tabular and graphical description of the main aspect for the success of outsourcing Source: Prepared by the authors.

Chart 8 shows that the largest percentage (50\%) regarding the main aspect for success of outsourcing is the need to contract specialists for certain services, followed by trust in the service provider (24\%) and the existence of complementary competencies (8\%), with $8 \%$ giving other reasons, shown in Chart 9.

\begin{tabular}{|c|c|c|c|c|}
\hline Variables & Categories & Freq. & $\%$ & Graphical Description \\
\hline \multirow{6}{*}{ 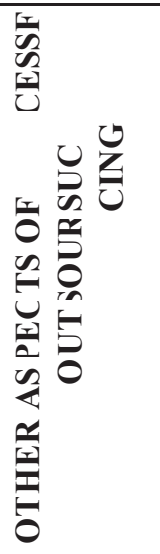 } & $\begin{array}{l}\text { A) Monitoring of the workers } \\
\text { by the service provision firm }\end{array}$ & 1 & $17 \%$ & \multirow[t]{6}{*}{ QUESTÃO 13: OUTROS } \\
\hline & $\begin{array}{l}\text { B) Communication and good } \\
\text { contractual compliance }\end{array}$ & 1 & $17 \%$ & \\
\hline & $\begin{array}{l}\text { C) Confidence, professional } \\
\text { specialization and references }\end{array}$ & 1 & $17 \%$ & \\
\hline & D) Reduction/control of costs & 2 & $33 \%$ & \\
\hline & $\begin{array}{l}\text { E) Satisfactory low-cost } \\
\text { services that are not the main } \\
\text { focus of the company }\end{array}$ & 1 & $17 \%$ & \\
\hline & Total & 6 & $100 \%$ & \\
\hline
\end{tabular}

Chart 9 - Tabular and graphical description of other important reasons for the success of outsourcing Source: Prepared by the authors. 
Note that among the other important aspects for the success of outsourcing, the most indicated was reduction or control of costs $(33 \%)$. The other aspects were mentioned with the same percentage (by one company each).

In the opinion of the respondent managers, the leading aspect for the success of outsourcing is the need to contract specialists. This reflects the tendency in the market in which the clients of service provision firms are increasingly demanding and not willing to deliver their activities to professionals who are not qualified to perform their functions.

Besides the assurance that the outsourced activities will be performed by qualified people, there is a need to maintain a relationship of partnership and commitment with the service firm. This requires mutual confidence and trust between the parties, an aspect that appears second most important for the success of outsourcing.

\subsubsection{Factors and activities of outsourced services}

To verify whether there is a relationship of dependency between the activities and factors that prompt companies to outsource their services, we prepared a contingency table to cross-reference these variables and applied Pearson's Chi-square test. The test hypotheses are the following:

$\mathbf{H}_{\mathbf{0}}$ : There is no relationship between the type of service and the factor motivating outsourcing.

$\mathbf{H}_{\mathbf{a}}$ : There is a dependence relationship between the type of service and the factor motivating outsourcing.

Table 1 - Observed and expected values (between parentheses) from cross-referencing the activities and factors that lead companies to outsource services

\begin{tabular}{|c|c|c|c|c|c|c|}
\hline FACTORS & Logistics & $\begin{array}{l}\text { Information } \\
\text { technology }\end{array}$ & $\begin{array}{l}\text { Parts of the } \\
\text { production } \\
\text { process }\end{array}$ & $\begin{array}{c}\text { Gate keeping } \\
\text { and/or reception } \\
\text { desk }\end{array}$ & Cleaning & TOTAL \\
\hline 0 & $43(34)$ & $45(34)$ & $42(34)$ & $22(34)$ & $17(17)$ & 169 \\
\hline 1 & $6(15)$ & $15(15)$ & $6(15)$ & $24(15)$ & $23(15)$ & 74 \\
\hline 2 & $5(8)$ & $5(8)$ & $5(8)$ & $10(8)$ & $15(8)$ & 40 \\
\hline 3 & $1(1)$ & $1(1)$ & $4(1)$ & $0(1)$ & $1(1)$ & 7 \\
\hline 4 & $1(2)$ & $6(2)$ & $1(2)$ & $0(2)$ & $0(2)$ & 8 \\
\hline 5 & $3(3)$ & $1(3)$ & $6(3)$ & $2(3)$ & $3(3)$ & 15 \\
\hline 6 & $2(3)$ & $1(3)$ & $1(3)$ & $5(3)$ & $4(3)$ & 13 \\
\hline 7 & $2(2)$ & $2(2)$ & $2(2)$ & $1(2)$ & $1(2)$ & 8 \\
\hline 8 & $10(11)$ & $2(11)$ & $12(11)$ & $15(11)$ & $14(11)$ & 53 \\
\hline 9 & $3(1)$ & $0(1)$ & $0(1)$ & $0(1)$ & $0(1)$ & 3 \\
\hline 10 & $3(1)$ & $1(1)$ & $1(1)$ & $0(1)$ & $1(1)$ & 6 \\
\hline TOTAL & 79 & 79 & 80 & 79 & 79 & 396 \\
\hline \multicolumn{3}{|c|}{ Legend of the Factors } & \multicolumn{4}{|c|}{$0=$ No outsourcing of this service } \\
\hline \multicolumn{3}{|c|}{$1=$ Specialization of the service provider } & \multicolumn{4}{|c|}{$2=$ Increased focus on main activity } \\
\hline \multicolumn{3}{|c|}{$3=$ Increased productivity } & \multicolumn{4}{|c|}{$4=$ Acquisition and updating of new technologies } \\
\hline \multicolumn{3}{|c|}{$5=$ Absence of internal resources } & \multicolumn{4}{|c|}{$6=$ Improved quality of services } \\
\hline \multicolumn{3}{|c|}{$7=$ Increased flexibility in management } & \multicolumn{4}{|c|}{$8=$ Reduction and control of operating costs } \\
\hline \multicolumn{3}{|c|}{$9=$ Reduction of assets on the balance sheet } & \multicolumn{4}{|c|}{$10=$ Increased competitiveness of the company } \\
\hline
\end{tabular}




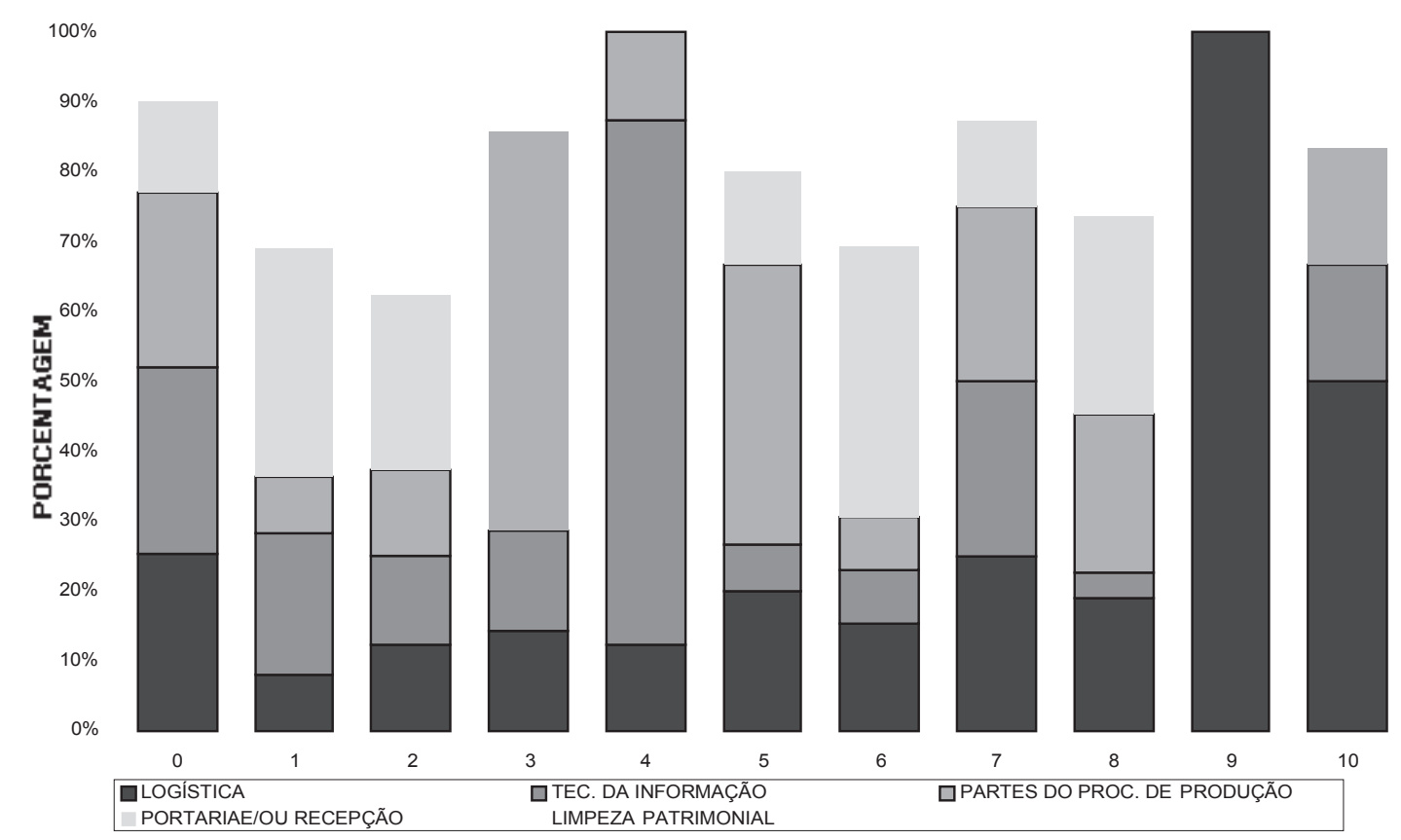

Source: Prepared by the authors.

Table 1 describes the 396 responses, considering that each company can outsource more than one type of service, and for different importance factors. The Chi-square test showed a dependence relation between the activities, with a p-value $<0.001$, i.e., there is strong statistical evidence that the activities outsourced and the factors of outsourcing are related. In this sense, there are strong indications confirming hypothesis $\mathrm{H}_{\mathrm{a}}$ "There is a dependence relationship between the type of service and the factor motivating outsourcing". The graph shows that factor 9 was the only one declared for logistics activity, while factor 4 was most often mentioned in the context of information technology. Factors 1, 2, 5, 6, 7 and 8 were involved in all the activities.

Given that the factors (1) specialization of the service provider, (2) increased focus on main activity and (8) reduction and control of operating costs appear more often than the others, we applied a pairwise independence test between them to verify if there is any difference in the activities. Tables 2,3 and 4 present the results.

Table 2 - Observed and expected values (between parentheses) from the cross-referencing between the activities and factors "specialization of the service provider" and "increased focus on main activity".

\begin{tabular}{ccccccc}
\hline FATORES & Logistics & $\begin{array}{c}\text { Information } \\
\text { technology }\end{array}$ & $\begin{array}{c}\text { Parts of the } \\
\text { production } \\
\text { process }\end{array}$ & $\begin{array}{c}\text { Gate keeping } \\
\text { and/or } \\
\text { reception } \\
\text { desk }\end{array}$ & Cleaning & TOTAL \\
\hline 01 & $6(7)$ & $15(13)$ & $6(7)$ & $24(22)$ & $23(25)$ & 74 \\
02 & $5(4)$ & $5(7)$ & $5(4)$ & $10(12)$ & $15(13)$ & 40 \\
\hline TOTAL & $\mathbf{1 1}$ & $\mathbf{2 0}$ & $\mathbf{1 1}$ & $\mathbf{3 4}$ & $\mathbf{3 8}$ & $\mathbf{1 1 4}$ \\
\hline
\end{tabular}

Source: Prepared by the authors. 
The Chi-square test showed the lack of dependence between these two factors, with respect to the activities outsourced, with a p-value of $0.60(p>0.05)$, i.e., the two factors have the same importance for the companies, independent of the activities.

Table 3 - Observed and expected values (between parentheses) from the cross-referencing between the activities and factors "specialization of the service provider" and "reduction and control of operating costs".

\begin{tabular}{ccccccr}
\hline FACTORS & Logistics & $\begin{array}{c}\text { Information } \\
\text { technology }\end{array}$ & $\begin{array}{c}\text { Parts of the } \\
\text { production } \\
\text { process }\end{array}$ & $\begin{array}{c}\text { Gate keeping } \\
\text { and/or } \\
\text { reception } \\
\text { desk }\end{array}$ & Cleaning & TOTAL \\
\hline 01 & $6(9)$ & $15(10)$ & $6(10)$ & $24(23)$ & $23(22)$ & 74 \\
08 & $10(7)$ & $2(7)$ & $12(8)$ & $15(16)$ & $14(15)$ & 53 \\
\hline TOTAL & $\mathbf{1 6}$ & $\mathbf{1 7}$ & $\mathbf{1 8}$ & $\mathbf{3 9}$ & $\mathbf{3 7}$ & $\mathbf{1 2 7}$ \\
\hline
\end{tabular}

Source: Prepared by the authors.

In this case, the Chi-square test showed dependency between the two factors, in relation to the outsourced activities, at a p-value of $0.007(p<0.05)$, i.e., statistically, the importance of these two factors depends on the activities. Furthermore, the information technology activity garnered more indications of importance for the "specialization of the service provider" than would be expected under $\mathrm{H}_{0}$, while for "reduction and control of operating costs" the occurrence was less than expected under $\mathrm{H}_{\mathrm{o}}$. For the factors "parts of the production process" and "logistics" the opposite occurred.

Table 4 - Observed and expected values (between parentheses) from the cross-referencing between the activities and factors "increased focus on main activity" and "reduction and control of operating costs". \begin{tabular}{llllll}
\hline FACTORS Logistics Information Parts of the Gate keeping Cleaning TOTAL &
\end{tabular} technology production and/or reception

\begin{tabular}{|c|c|c|c|c|c|c|}
\hline & & & & & & \\
\hline 02 & $5(6)$ & $5(3)$ & $5(7)$ & $10(11)$ & $15(12)$ & 40 \\
\hline 08 & $10(9)$ & 2(4) & $12(10)$ & $15(14)$ & $14(17)$ & 53 \\
\hline TOTAL & 15 & 7 & 17 & 25 & 29 & 93 \\
\hline
\end{tabular}

Source: Prepared by the authors.

As shown in Table 4, the observed and expected values are very near. Consequently, the Chi-square test indicated the lack of dependence of these two factors in relation to the activities that are outsourced, with a p-value of $0.27(p>0.05)$, i.e., statistically, they have equal importance for the companies, independent of the activities.

Table 5 shows the p-values for the cross-referencing of all the factors of importance.

The values in boldface represent p-values less than 0.05 , thus indicating a dependence relationship between the two factors regarding the activities involved. The \# symbol indicates no value could be obtained by the test because of the very small number of responses. 
Table 5 -P-values obtained by the Chi-square test from the cross-referencing of the factors of importance

\begin{tabular}{|c|c|c|c|c|c|c|c|c|c|}
\hline & 1 & 2 & 3 & 4 & 5 & 6 & 7 & 8 & 9 \\
\hline 2 & 0.60 & & & & & & & & \\
\hline 3 & 0.003 & 0.06 & & & & & & & \\
\hline 4 & 0.007 & 0.002 & \# & & & & & & \\
\hline 5 & 0.005 & 0.15 & 0.09 & 0.016 & & & & & \\
\hline 6 & 0.78 & 0.87 & 0.68 & 0.014 & 0.27 & & & & \\
\hline 7 & 0.19 & 0.42 & 0.68 & 0.32 & 0.75 & 0.38 & & & \\
\hline 8 & 0.006 & 0.27 & 0.16 & $<0.001$ & 0.59 & 0.72 & 0.18 & & \\
\hline 9 & $<0.001$ & 0.006 & \# & \# & 0.12 & 0.09 & 0.29 & 0.33 & \\
\hline 10 & 0.021 & 0.16 & \# & \# & 0.5 & 0.27 & 0.8 & 0.19 & \# \\
\hline
\end{tabular}

Source: Prepared by the authors

\section{ANALYSIS OF THE RESULTS}

The results of the field study (quantitative and qualitative) associated with the literature review permit answering the central question of this study: Why do companies outsource their services? They also permit exploring in more detail the central objective of identifying the reasons that lead companies to outsource services rather than keep them inhouse.

From the data gathered and the perceptions obtained in the personal interviews with the executives, we can state that the firms studied outsource their services principally because of the following factors:

- Specialization of the service provider;

- Reduction and control of operating costs;

- Increased focus on the main activity.

The composition of these predominant factors also corroborates the findings of various other authors (Anderson \& Weitz, 1986; Belous, 1989; Pine II, 1994; Lever, 1997; Greer et al., 1999; Gupta \& Gupta, 1992; Kakabadse \& Kakabadse, 2002; McDonnell, Maehre \& Weiszmann, 2005). The three factors "specialization of the service provider", "reduction and control of operating costs" and "increased focus on the main activity" have the highest frequencies, as shown in Table 1. Hence, the decision about outsourcing a determined activity for the sample is contingent on the needs rather than a single factor.

An important finding is that the companies are willing to outsource only to specialists. In activities like information technology this is explained by the high professional qualification required in this area, and in activities like janitorial services and gatekeeping/reception, where the work itself does not require high qualification, the expectation is 
that a specialist company will reduce the costs and improve the quality of the services rendered. This result corroborates the study of Porter (1999, p. 49), according to whom "it is difficult to perform all activities as productively as specialists" and demonstrates this vision is shared by the majority of the managers.

Another result obtained in the qualitative study is that the companies are not willing to pay more for outsourcing than they would by keeping the activities in-house, even if they realize that a well-formulated subcontracting arrangement could provide other advantages, such as allowing the companies to focus more on their core activity and to acquire and update new technologies.

The companies consider that the central aspect for the success of outsourcing services rests mainly in the "contracting of specialists for the services", followed by "trust in the service provider".

The results reveal that the reason for outsourcing depends on the activity outsourced. The factor with highest frequency for the use of outsourcing was "specialization of the service provider", but this was only associated with three of the activities. The factor with the second highest frequency was "reduction and control of operating costs", but this was indicated for all the outsourced activities.

This finding is the result of the average determined for the five activities studied (logistics; information technology; parts of the production process; gate-keeping/reception; and cleaning). However, there is no uniformity regarding the factor in these five activities. For logistics and part of the productive process the main factor is "reduction and control of operating costs".

According to the result of classifying the factors and the independence test, it is possible to conclude that the factors "reduction and control of operating costs" and "increased focus on the main activity" have the same importance for the companies, irrespective of the activity involved.

As amply mentioned in the literature review, the factors "increased focus on the main activity" and "reduction and control of operating costs" are among the main reasons prompting firms to outsource services. We also observed this in the qualitative study.

The interviews with the managers showed that focus on the main activity by itself is not a defining reason for outsourcing, but associated with cost reduction, specialization of the service provider and acquisition of new technologies, among others, it strongly influences the 
decision to outsource. Therefore, the reasons for adopting outsourcing are associated with the activity and the economic segment of the company. These aspects influence the motivations for choosing to outsource services. So the claim that there is a universal main factor for outsourcing is not supported.

We sought to make a relation between the theories discussed in the theoretical section and the evaluations and decisions of the respondents regarding outsourcing services. None of the respondents literally follow a theory in this respect. In their evaluations pragmatism and professional experience prevails.

Being senior managers with solid academic backgrounds, they use their knowledge in these evaluations, such as of the cost-benefit relation of outsourcing versus internalizing an activity. Therefore, they carefully analyze the feasibility of each case, but as a rule do not do so in pedagogic or systematic form.

When questioned, one of the respondents disagreed with Williamson (1975) regarding the recommendation that recurring transactions involving a specific asset are not suited to being outsourced, but rather should be kept in-house.

The main argument used by this respondent was that there might be service providers able to carry out the referred activity better and at a lower cost. In a specific case, in fact, the company had even outsourced part of its production, which is highly recurrent and depends on specific assets. After several months the company was very satisfied with the result.

The respondents from the other companies agreed with Williamson, because their companies do not outsource the referred activities, limiting this to standardized services available in the market and keeping those that are recurring and depend on specific assets inside the company.

All the respondents agree with Porter (1999, p. 46) in his suggestion that companies "[...] must outsource aggressively to gain efficiencies." It is precisely this that the companies do when outsourcing various activities in search of efficiency and competitive advantages over their rivals.

In these managers' opinion, outsourcing is very important in strategic activities like logistics, because the companies depend on efficient distribution channels to meet all demand for their products in the domestic and external markets. 
Currently logistics is a highly outsourced segment and counts on experienced service providers that can distribute products globally at lower costs and faster than the manufacturer. Despite this, one of the companies surveyed undertook a careful process to select its logistics service provider, but still had to change to another after only six months due to substandard service. The reason was that the original provider had been unable to adjust to the regional distribution peculiarities required by the company. But even with this initial failure, the company opted not to vertically integrate this activity.

According to the respondents, the outsourcing of logistics services with good providers increases their firms' competitive advantage by reducing cost and improving distribution performance, giving them an edge over competitors. All the companies studied outsource this activity and intend to do so more intensely in the future. In this respect, the results are similar to those reported by Robles (2001).

All the companies also invest in the training and professional qualification of their employees with the aim of assuring the quality of their products. However, they do not see outsourcing of services as a threat to their core competencies, since when services are newly outsourced, normally part of the employees are transferred to the service provider (let go and rehired). Therefore, the investments by the company in training and qualification before the outsourcing are to some extent retained with the transfer of the services. Likewise, the competencies developed previously are maintained.

\section{FINAL CONSIDERATIONS}

The results of this study reveal that the areas least commonly outsourced are logistics, information technology and parts of production. This fact is related to the specificity of certain services - logistics, information technology and production are highly specific and can be understood as competencies of the company. The activities most often outsourced are janitorial services and gate-keeping/reception, respectively.

The high number of companies that outsource gate-keeping/reception and cleaning do so because of the specialization of the service providers. These activities, along with logistics, were indicated by some companies as a way to reduce costs. Besides cost savings, the explanation for outsourcing the cleaning and gate-keeping/reception services is that these are not part of the central focus, as stressed by the theory of core competencies. Regarding the reasons for outsourcing in general, the companies do so because of the following factors: 
specialization of the service provider; reduction and control of operating costs; and increased focus on the main activity.

The present findings thus do not support the contention that there is a universal main factor responsible for the decision to outsource services. Instead, this decision relies on the interplay of a number of factors, such as the type of service and the economic segment of the service taker, making the decision to a great extent contingent on the company's business area.

Some limitations of this study should be noted, namely: the reduced territorial scope covered means the results cannot be extrapolated to the national level, and the focus on medium-sized and large industrial firms excluded small companies and other economic sectors (services, commerce and agriculture).

Despite these limitations, this study contributes to the understanding of the reasons why companies outsource their activities. There are few data on the outsourcing of services, especially by Brazilian companies, so there is a need for further research to shed more light on this theme. Therefore, other studies are necessary to gain a better understanding of the factors that facilitate and hamper the outsourcing process.

\section{REFERENCES}

ANDERSON, E.; WEITZ, B. A. Make-or-Buy Decisions: Vertical Integration and Marketing Productivity. Sloan Management Review, p. 3, v. 27, Iss. 3, Spring 1986.

BELOUS, R. S. Human Resource Flexibility and Equity: Difficult Questions for Business, Labor, and Government. Journal of Labor Research, p. 67, v. 10, Iss. 1, Winter 1989.

BUREAU OF NATIONAL AFFAIRS (BNA). Available at: www.bna.com. Retrieved on January 7, 2006.

BUSI, M.; McIVOR, R. Setting the outsourcing research agenda: the top-10 most urgent outsourcing areas. Strategic Outsourcing: An International Journal, vol. 1 n. 3, pp. 185-197, 2008.

BYRNE, J. A. Has Outsourcing Gone Too Far? It's the corporate rage, but farming out work can cost a company dearly. Business Week. New York, p. 26, Iss. 3469, April 1, 1996.

COLlinS, J.; HUSSEY, R. Pesquisa em Administração. Porto Alegre: Bookman, 2005.

FERNANDES, M. E. R.; CARVALHO NETO, A. M. Gestão dos Múltiplos Vínculos Contratuais nas Grandes Companys Brasileiras. Doctoral Thesis in Business Administration, São Paulo: USP, 2005.

GONZALEZ, R.; GASCO, J. LLOPIS, J. Information systems outsourcing reasons and risks: a new assessment. Industrial Management \& Data Systems, vol. 110, n. 2, pp. 284-303, 2010.

GREER, C. R.; YOUNGBLOOD, S. A.; GRAY, D. A. Human Resource Management Outsourcing: The Make or Buy Decision. Academy of Management Executive, p. 85, v. 13, Iss. 3, Aug. 1999. 
GUPTA, U.; GUPTA, A. Outsourcing the IS Function: Is it Necessary for your Organization? Information Systems Management, p. 44, v. 9, Iss. 3, Summer 1992.

HAMEL, G.; PRAHALAD, C. K. Competing for the Future. Harvard Business Review, p. 122, vol. 72, Iss. 4, 1994.

HAMEL, G.; PRAHALAD, C. K. A Competência Essencial da Corporação, HBR May-June 1990, in Estratégica, organized by Montgomery, C. A. \& Porter, M. A., Rio de Janeiro: Campus, 1998.

HESSEL, R. P\&G Fecha Contrato de US\$ 400 million com a IBM e Terceiriza RH. Jornal Gazeta Mercantil. São Paulo: September 10, 2003.

IBGE - Instituto Brasileiro de Geografia e Estatística. Site www.ibge.gov.br. Accesses on November 2, 2005, February 25, 2006, May 20, 2006 and April 18, 2007.

JAGERSMA, P. K.; VAN GORP, D. M. Redefining the paradigm of global competition: offshoring of service firms, v. 8 n., pp. 35-42, Business strategy series, 2007.

JENSTER, P. V.; PEDERSEN, H. S. Outsourcing - Facts and Fiction. Strategic Change. ABI/INFORM Global, pp. 147-154, v. 9, Iss. 3, May 2000.

JIANG, B.; QURESHI, A. Research on outsourcing results: current literature and future opportunities. Management Decision, v. 44, n. 1 pp. 44-55, 2006.

JORNAL FOLHA DE S. PAULO. Índia Exporta Tecnologia e vira Pólo de Terceirização de Serviços. Site folha.com.br. Caderno Dinheiro. São Paulo. Accessed on July 18, 2006.

KAKABADSE, A.; KAKABADSE, N. Trends in Outsourcing: Contrasting USA and Europe. European Management Journal, p. 189-198, v. 20, Iss. 2, April 2002.

LACITY, M. C.; HIRSCHHEIM, R. Information System Outsourcing: Myths, metaphors and realities. New Jersey: Prentice-Hall, 1993.

LEVER, S. An Analysis of Managerial Motivations behind Outsourcing Practices in Human Resources. Human Resource Planning, p. 37, v. 20, Iss. 2, 1997.

LILLY, J. D.; GRAY, D. A.; VIRICK, M. Outsourcing the Human Resource Function: Environmental and Organizational Characteristics that Affect HR Performance. Journal of Business Strategies, p. 55, v. 22, Iss. 1, Spring 2005.

McDERMOTT, M. A. An Empirical Investigation of Core Competence and Firm Performance. A Dissertation submitted to the University at Albany, State University of New York in partial fulfillment of the requirements for the Degree of Doctor of Philosophy. 2003.

McDONNELL, P. H.; MAEHRE, A.; WEISZMANN, C. Outsourcing Continues: Pursuing a Best Sourcing Strategy. Insurance \& Technology. New York, p. S1, vol. 30, Iss. 10, Oct 2005.

MOSES, A.; AHLSTROM, P. Dimensions of change in make or buy decision processes.

Strategic Outsourcing: an International Journal, v. 1, n. 3, pp. 230-251, 2008.

PEREIRA, J. C. R. Análise de Dados Qualitativos: Estratégias Metodológicas para as Ciências da Saúde, Humanas e Sociais. EDUSP/FAPESP, p. 77, 2001.

PIMENTEL GOMES, F. Curso de Estatística Experimental. São Paulo: Livraria Nobel, 14th ed., 2000.

PIRES, S. R. I. Gestão da Cadeia de Suprimentos: conceitos, estratégias, práticas e casos Supply Chain Management. S. Paulo: Atlas, 2004. 
POLONIO, W. A. Terceirização - Aspectos Legais, Trabalhistas e Tributários. S. Paulo: Atlas, 2000.

PORTER, M. E. Estratégias Competitivas. Rio de Janeiro: Campus, 1986.

PORTER, M. E. Competição: Estratégias competitivas essenciais. 8th ed. Rio de Janeiro: Campus, 1999.

QUINN, J. B.; DOORLEY, T. L.; PAQUETTE, P. C. Technology in Services: Rethinking Strategic Focus. Sloan Management Review, p. 79-87, vol. 31, Iss. 2, Winter 1990.

QUINN, J. B.; HILMER, F. G. Strategic Outsourcing. Sloan Management Review, p. 43, vol. 35, 4, 1994.

ROBLES, L. T. A Prestação de Serviços de Logística Integrada na Indústria Automobilística no Brasil: em busca de alianças logísticas estratégicas. Doctoral Thesis in Business Administration, São Paulo: USP, 2001.

SPIEGEL, Y. Horizontal Subcontracting. The Rand Journal of Economics, p. 570, vol. 24, no. 4, 1993.

WILLIAMSON, O. E. Markets and Hierarchies: Analysis and Antitrust Implications. New York: The Free Press, 1975.

WILLIAMSON, O. E. The Economic Institutions of Capitalism: Firms, Markets, Relational Contracting. New York: The Free Press, 1985.

\footnotetext{
${ }^{\mathrm{i}}$ These liabilities can arise from lawsuits filed by current or former employees of the service provision firms, claiming the outsourcing arrangement was fraudulent to avoid paying all their labor rights, or from the liability (either subsidiary or joint and several) of the service taker for unmet labor obligations of the service provider firm.
} 